\title{
CINGCOWONG DARI sAKRAL KE PROFAN
}

\section{CINGCOWONG FROM SACRED TO PROFANE}

\author{
Oleh Risa Nopianti \\ Balai Pelestarian Nilai Budaya Bandung \\ Jalan Cinambo No.136 Ujungberung Bandung \\ Email : risanopianti@gmail.com
}

Naskah Disetujui: 1 April 2013

\begin{abstract}
Abstrak
Cingcowong sebagai sebuah ritual tradisional yang berasal dari masyarakat agraris Desa Luragung Landeuh, Kabupaten Kuningan, merupakan wujud aktifitas kolektif masyarakat yang bersumber pada kepercayaan terhadap roh-roh gaib yang dipercaya memiliki kekuatan mampu mendatangakan hujan untuk mengatasi kekeringan, khususnya pada lahan pertanian yang disebabkan oleh kemarau berkepanjangan. Seiring dengan berkembangnya pengetahuan masyarakat terhadap konsep keagamaan dan nilainilai spiritual, ritual Cingcowong yang dahulu dianggap memiliki nilai sakral, saat ini mulai luntur dan berganti dengan nilai-nilai yang bersifat profan. Pada perkembangannya saat ini Cingcowong tidak saja dianggap sebagai ritual sakral tetapi juga dianggap sebagai bentuk budaya yang bersifat hiburan karena telah bertansformasi dalam bentuk kesenian khususnya seni tari Cingcowong. Adanya perubahan paradigma terhadap nilai-nilai sakral ke profan dalam ritual Cingcowong oleh sebagian besar masyarakat, selain disebabkan oleh faktor eksternal perubahan fungsi, juga disebabkan oleh adanya faktor internal dalam ritual Cingcowong itu sendiri. Faktor internal tersebut berkaitan dengan perubahan dalam hal pemenuhan kebutuhan hidup yang dihadapi oleh para pelakunya, sehingga ritual Cingcowong menjadi komersial. Penelitian ini dilakukan melalui metode kualitatif dengan pemaparan deskriptif analitik untuk menghasilkan gambaran dan analisa lengkap terhadap fenomena yang diajukan.
\end{abstract}

Kata kunci : Cingcowong, Ritual, Sakral, Profan

\begin{abstract}
Cingcowong is atraditional ritual of agrarian community in Desa (village) Luragung Landeuh, Regency of Kuningan. It is a manifestation of collective activities that has root in belief on spirits which is believed to have power to make rain during drought. As the community have more knowledge about religious concepts and spiritual values, cingcowong ritual which was considered sacred is beginning to vanish, turned into profane values. Today cingcowong is also considered as a form of entertaining culture due to its transformation into a kind of art, especially cingcowong dance. The switch of paradigm was caused by external factor in term of its function, and internal factors as well. The internal factors are related to changes in subsistence faced by the community so
\end{abstract}


that cingcowong has become commercial. The author conducted a qualitative research method with a brief descriptive analytics exposition to produce comprehensive overview and analysis of the phenomenon proposed.

Keywords: Cingcowong, ritual, sacred, profane

\section{A. PENDAHULUAN}

Manusia, kebudayaan dan lingkungan, merupakan 3 faktor yang saling menjalin secara integral. Lingkungan tempat manusia hidup selain berupa lingkungan alam juga berupa lingkungan sosial budayanya. Sehubungan dengan itu, maka konsep manusia harus dipahami sebagai makhluk yang bersifat biososiobudaya. Kaidah biologis yang menuntut kemampuan organisme melakukan penyesuaian diri terhadap lingkungan, berlaku pula untuk lingkungan sosiobudayanya (Adimihardja, 1993:1).

Kehidupan masyarakat di perdesaan yang masih bersahaja, berkaitan erat dengan kondisi alam dan lingkungan mereka. Sebuah keniscayaan apabila mereka sangat bergantung pada alam dan mendayagunakannya sedemikian rupa sehingga mampu memberikan manfaat bagi kehidupan mereka. Salah satu hal yang banyak dimanfaatkan oleh masyarakat di perdesaan adalah lahan pertanian dan hutan.

Pertanian sebagai penyokong utama kehidupan masyarakat di perdesaan memiliki makna yang sangat penting bagi kehidupan masyarakat setempat. Itulah sebabnya kehidupan masyarakat desa selalu berpusat pada sistem dan siklus pertanian. Ketergantungan yang tinggi akan lahan dan hasil pertanian membuat masyarakat begitu menghargai dan menghormati keberadaan lahan pertanian mereka. Salah satu bentuk penghormatan masyarakat terhadap lahan pertanian adalah adanya ritual-ritual pertanian yang dimaksudkan supaya tanaman pertanian dapat tumbuh dan berkembang dangan baik sehingga dapat menghasilkan panen yang berlimpah.

Adanya upaya masyarakat untuk menjaga, menghormati dan menghargai lingkungan alam mereka, secara umum merupakan sebuah upaya untuk menjaga keseimbangan lingkungan. Untuk itu diperlukan adanya pengelolaan alam yang baik guna menjaga keseimbangan lingkungan ekologis mereka. Pengelolaan yang biasa dilakukan antara lain melalui pranata sosial budaya dan kepercayaan mereka, misalnya dengan adanya pelbagai ritual, pantangan tradisional atau tabu (Iskandar, 1992:5)

Ritual merupakan sebuah kegiatan kolektif yang didasari oleh adanya kepercayaan bersama terhadap sesuatu hal yang bersifat gaib, mistis dan sakral. Ritual 
dapat berkaitan dengan kegiatan agama dan dapat pula di luar agama. Hal ini disebabkan ritual terhadap sesuatu yang suci memiliki fungsi yang lebih luas dari agama, sehingga ritual tidak hanya dapat disematkan pada agama tetapi juga terhadap multidimensi kehidupan manusia.

Mungkin lebih tepatnya ritual dapat dikatakan sebagai bagian dari fenomena religius bukan agama, karena antara agama atau kepercayaan dan ritual atau ritus ternyata memiliki makna yang berbeda namun saling terkait satu sama lain. Sebagaimana yang diungkapkan oleh Pals (2011) berikut ini,

"Religious phenomena fall into two basic categories: beliefs and rites. The first are states of opinion and consist of representations; the second are particular modes of action. Between these two categories of phenomena lies all that separates thinking from doing".

Hubungan kausalitas antara manusia, lingkungan, budaya dan kepercayaan sebagaimana yang diuraikan di atas dapat dilihat dari fenomena Cingcowong yang berasal dari daerah Luragung, Kabupaten Kuningan, Jawa Barat. Cingcowong merupakan sebuah ritual yang dipercaya oleh masyarakat mampu mendatangkan hujan. Fenomena ini terjadi manakala masyarakat setempat merasa begitu menderita ketika lahan pertanian yang menjadi tumpuan hidupnya tidak mampu lagi memberikan penghidupan bagi mereka. Kemarau panjang yang menjadi faktor utama kekeringan yang terjadi atas lahan pertanian mereka kemudian menjadi sebuah hal yang sangat ditakuti. Fenomena kemarau yang berkepanjangan yang terjadi di daerah Luragung, kemudian disikapi oleh seseorang yang disebut punduh dengan menggelar ritual pemanggilan hujan.

Ritual Cingcowong yang menjadikan boneka sebagai perantara bagi manusia yang dipimpin oleh punduh untuk berkomunikasi dengan makhluk gaib memiliki kekuatan besar untuk mendatangkan hujan. Adanya campur tangan makhluk gaib dalam ritual ini menjadikan ritual Cingcowong sebagai suatu hal yang disakralkan oleh masyarakat setempat. Dengan pembuktian-pembuktian terjadinya hujan setelah ritual digelar, perlahan namun pasti ritual Cingcowong kemudian dipercaya oleh masyarakat sebagai jawaban atas kemarau panjang yang mereka alami.

Kondisi ini berlangsung cukup lama hingga ritual Cingcowong dipimpin oleh punduh generasi ketiga. Namun setelah digantikan dengan punduh generasi keempat terjadi beberapa perubahan yang cukup signifikan terhadap ritual Cingcowong ini. Konsep sakral yang tersemat dalam ritual Cingcowong perlahan terkikis karena adanya penolakan dari sebagian masyarakat yang menganggap bahwa ritual yang ada 
bertentangan dengan syariat agama. Oleh sebab itulah, saat ini ritual Cingcowong telah berkembang pada konsep lain yang bersifat profan yaitu kesenian. Konsep ini diharapkan mampu menjawab kegamangan masyarakat terhadap keberadaan ritual Cingowong, namun di sisi lain dapat mempertahankan keberadaan tradisi ritual Cingcowong supaya tidak hilang tergerus waktu. Selain alasan tersebut, apa sajakah sebenarnya yang menjadi penyebab terjadinya perubahan tradisi ritual Cingcowong dari sakral menjadi profan?

Dalam bukunya "The Elementary Forms of the Religious Life", Emile Durkheim menyebutkan society (masyarakat) adalah struktur dari ikatan sosial yang dikuatkan dengan konsensus moral. Durkhiem juga mengungkapkan bahwa agama suatu masyarakat memiliki fungsi sebagai penguat solidaritas sosial. Lewat buku tersebut Durkheim ingin melihat agama dari bentuknya yang paling sederhana sampai ke agama yang well-structured dan well-organised. Durkheim menemukan bahwa aspek terpenting dalam pengertian agama adalah adanya distingsi antara yang sacred (sakral) ${ }^{1}$ dan yang profane $^{2}$.

Durkheim menyatakan bahwa dasar dari kepercayaan terhadap agama bukanlah terletak pada kepercayaan terhadap hal-hal yang supernatural seperti Tuhan, karena pada banyak agama tidak ditemukan kepercayaan terhadap Tuhan. Ini berarti, asumsi Tylor \& Frazer yang menyatakan pemahaman akan fenomena alam yang didasari oleh kekuatan supernatural adalah hakikat dari agama tidaklah tepat. Dasar dari agama bukanlah kepercayaan terhadap kekuatan supernatural (pembedaan atas apa yang natural dan supernatural), melainkan konsep The Sacred (Yang Sakral). Pada masyarakat beragama, terdapat dua konsep yang terpisah, yaitu Yang Sakral dan Yang Profan.

Durkheim menyebutkan bahwa the Sacred merupakan pengalaman kemasyarakatan yang menjadi lambang kebersatuan transenden yang dimanifestasikan dalam simbol-simbol masyarakat, sementara the Profane merupakan pengalaman individual yang dianggap lebih rendah dari pengalaman sakral. Pada masyarakat sederhana sekalipun, masyarakat telah mampu membedakan mengenai hal-hal yang dianggap sakral dan hal-hal yang dianggap profan atau duniawi.

Durkheim memberikan contoh mengenai hal-hal yang bersifat sakral dan profan sebagaimana berikut ini,

\footnotetext{
${ }^{1}$ Secred (sakral) adalah sesuatu yang tinggi, agung, berkuasa, dihormati, dalam kondisi profan ia tidak tersentuh dan terjamah.

${ }^{2}$ Profane (profan) adalah Sesuatu yang biasa, bersifat keseharian, hal-hal yang dilakukan seharihari secara teratur dan acak, dan sebenarnya tidak terlalu penting.
} 
"Beliefs, myths, dogmas, and legends are either representations or systems of representations that express the nature of sacred things. The virtues and powers attributed to them, their history, and their relationships with one another as well as with profane things" (Durkheim, 1995: 109).

The secred (yang keramat) dan ritual-ritual yang ada di masyarakat jauh lebih luas cakupannya daripada agama. The secred merupakan sebuah ikatan primodial masyarakat yang memiliki sifat mempersatukan. Hal yang bersifat menyatukan ini disebut sebagai secred center. Secred center adalah fokus identitas kolektif masyarakat sekaligus regula prima masyarakat tersebut. The secred adalah sumber solidaritas masyarakat (Sutrisno dan Putranto, 2005:101).

The secred sebagai suatu nilai kultural kolektif dan pengikat identitas diabadikan dalam memori kolektif. The secred bersumber dari peristiwa sejarah yang kemudian dimodifikasi oleh kalangan tertentu sehingga tercipta sebuah kesan keramat atas peristiwa atau fenomena tersebut. Makna kolektif dapat menjadi memori kolektif karena ada sharing of experience, merasakan pengalaman yang sama atau berkat proses sosialisasi. Sosialisasi ini dipelihara turun temurun melalui perayaan, ritus-ritus, upacara, penulisan sejarah dan narasi dari mulut ke mulut (Sutrisno dan Putranto, 2005:104).

Sifat mensakralkan suatu fenomena atau benda tidak dapat dilepaskan dari adanya kesadaran kolektif (collective belief) pada masyarakat pendukungnya. Kesadaran kolektif (collective belief) merupakan pendorong sebuah gagasan kolektif (representations collectives). Adapun gagasan kolektif bermula dari gagasan individu (reprsentations individual). Oleh karena suatu masyarakat ada banyak manusia hidup bersama, maka gagasan-gagasan dari sebagian besar individu yang menjadi masyarakat tergabung menjadi kompleks-kompleks yang lebih tinggi yaitu gagasan kolektif (Koentjarangirat, 1987:91).

Penelitian ini dilakukan melalui metode kualitatif dengan pemaparan deskriptif analitik. Kegiatan penelitian dilakukan melalui serangkaian tahap, dimulai dengan mengidentifikasi masalah, mengembangkan hipotesis, mengumpulkan dan menganalisa data hingga menarik suatu kesimpulan (Narbuko dan Achmadi, 2012:3). Pada tahap pengumpulan data dilakukan metode observasi dan interview. Adapun dalam tahap pengembangan hipotesis dan analisis data dilengkapi dengan teori-teori yang disusun secara sistematis melalui proses yang intensif untuk menarik kesimpulan secara general.

\section{B. HASIL DAN BAHASAN}


Ritual sebagai sebuah kegiatan yang berkaitan dengan sistem kepercayaan masyarakat telah lama hadir dalam kehidupan masyarakat seiring dengan proses berkembangnya pemikiran dan pemahaman manusia terhadap segala sesuatu yang dianggap memiliki kekuatan besar dan gaib. Cingcowong sebagai bentuk ritual masyarakat di Desa Luragung Landeuh, Kecamatan Luragung Kabupaten Kuningan merupakan represntasi kesadaran masyarakat terhadap adanya kekuatan alam yang besar dan gaib itu, yang mereka yakini mampu mendatangkan hujan.

Sebagai sebuah ritual yang bersifat sakral, Cingcowong telah menginternal dalam diri masyarakat pendukungnya dari generasi ke generasi. Namun kenyataan saat ini berbeda, manakala Cingcowong telah berubah fungsinya yang tidak lagi semata menjalankan fungsi ritual sakral, tetapi dapat juga dilaksanakan dalam nuansa profan seperti dalam berbagai kegiatan kesenian, hingga pertunjukan budaya dan penelitian. Kondisi ini tentu saja berakibat pada lunturnya nilai-nilai yang telah menginternal pada masyarakat tadi. Fenomena inilah yang coba untuk ditelusuri penyebabnya sehingga ke depan dapat diketahui hal-hal apa saja yang perlu dilakukan untuk menyelamatkan tradisi ini dari ketidakperdulian masyarakat yang pada akhirnya dapat memunahkannya.

\section{Cingcowong Ritual Memanggil Hujan}

Menurut Kusnadi, Cingcowong adalah seni ritual untuk meminta hujan dengan media jejelmaan atau orang-orangan perempuan berwajah cantik dan cara untuk memanggil roh-roh (gaibnya) dengan alat pengiring buyung yang terbuat dari tanah liat (sebagai kendang) dan ceneng (bokor) sebagai ketuk (Kusnadi, 2001: 18-19). Secara harfiah Cingcowong berasal dari kata cing dan cowong. Kata cing dalam bahasa Sunda memiliki arti yang sama dari kata $c i k$, yang berarti coba dalam bahasa Indonesia. Kata cowong dalam bahasa Indonesia berarti biasa berbicara keras.

Peristiwa yang melatarbelakangi diselenggarakannya upacara ini adalah terjadinya kemarau panjang yang mengakibatkan kekeringan sehingga berdampak pada penghasilan masyarakat yang mayoritas adalah petani. Hal ini sesuai dengan cerita yang dituturkan Nawita dan cerita lisan masyarakat Luragung pada umumnya bahwa kehadiran Cingcowong disebabkan oleh suatu keadaan yang mendesak dan darurat. Pada masa lalu di daerah Luragung terjadi kemarau yang panjang sehingga para petani menjadi resah. Sawah dan ladang para petani banyak yang gagal panen akibat dilanda kekeringan. 
Pada situasi sulit tersebut, Rantasih seorang warga Luragung kemudian mengajak masyarakat untuk mencari sumber mata air. Akan tetapi usahanya gagal karena masyarakat yang sudah terlanjur putus asa tidak bersedia memenuhi ajakannya. Pada saat Rantasih mengalami kesulitan mengumpulkan masyarakat untuk bersama-sama berdoa, muncul gagasan untuk memukul ceneng berulang kali hingga masyarakat berkumpul. Upaya tersebut ternyata cukup berhasil. Ia kemudian menyampaikan petunjuk yang datang pada saat tirakat, yaitu dengan cara tidak makan, tidak minum, dan tidak tidur selama tiga hari tiga malam, bahwa cara meminta hujan adalah dengan melakukan upacara ritual melalui media boneka Cingcowong. Lambat laun masyarakat mulai percaya bahwa ternyata ritual Cingcowong tersebut dianggap manjur untuk mendatangkan hujan. Hal ini terbukti setiap ritual selesai digelar, hujan selalu turun sesuai dengan keinginan masyarakat.

Ritual Cingcowong dipimpin oleh seorang yang dinamakan punduh. Punduh adalah orang yang dianggap memiliki kemampuan khusus di bidang agama atau kepercayaan setempat yang diperolehnya karena inisiatif sendiri, dan dianggap memiliki kecakapan khusus untuk berhubungan dengan makhluk dan kekuatan supernatural.

Punduh pertama tidak diketahui namanya, namun punduh yang pertama kali dikenal bernama Rantasih. Ia kemudian mewariskannya kepada puterinya yang bernama Rasih yang mengelola upacara ini sampai tahun 1930 dan meninggal dalam usia 90 tahun sebagai generasi kedua pengelola upacara Cingcowong. Tahun 1930 sampai tahun 1980, upacara Cingcowong dikelola oleh Suki, yang merupakan cucu dari Rantasih. Suki meninggal dalam usia 70 tahun sebagai generasi ketiga pengelola upacara Cingcowong. Sejak tahun 1981 sampai sekarang, upacara Cingcowong dikelola Nawita, cucu dari Rasih dan merupakan generasi keempat.

\section{a. Persiapan Upacara Cingcowong}

Dalam setiap pagelarannya, upacara Cingcowong yang terdapat di Kampung Wage, Desa Luragung Landeuh, Kecamatan Luragung ini dimainkan oleh enam orang yang memiliki tugas masing-masing, di antaranya:

1) Ibu Nawita sebagai punduh. Punduh merupakan pemimpin upacara Cingcowong yang dengan kemampuannya dipercaya masyarakat setempat dapat mendatangkan hujan melalui perantara boneka Cingcowong. 
2) Hj. Itit dan Nining Waskini sebagai pembantu punduh, mereka bertugas membantu punduh Nawita dalam memegang boneka Cingcowong.

3) Ibu warsinah memainkan alat musik berupa buyung, yang biasa dipakai sebagai alat penyimpan air terbuat dari tanah liat.

4) Ibu Kaseh memainkan alat musik berupa bokor atau ceneng yang biasa dipakai sebagai vas bunga, terbuat dari bahan tembaga/kuningan.

5) Ibu Wartinah berperan sebagai Sinden.

Adapun peralatan yang biasa dipergunakan untuk upacara yaitu :

1) Taraje atau tangga yang terbuat dari bambu yang berfungsi untuk membawa atau menyambut turunnya arwah lelembut atau dalam peribahasa untuk menyambut turunnya bidadari.

2) Samak atau tikar yang terbuat dari anyaman pandan, yang berfungsi sebagai alas tempat duduk pada pagelaran tersebut.

3) Sisir dipergunakan untuk menata rambut boneka Cingcowong pada saat upacara berlangsung.

4) Cermin yang difungsikan sebagai alat bagi punduh untuk memperlihatkan bentuk dan raut wajah boneka Cingcowong kepada para bidadari yang akan memasuki tubuh boneka Cingcowong.

5) Bunga kamboja yang dicampur dengan air yang dipergunakan sebagai saweran pada sesi terakhir upacara Cingcowong. Saweran bunga kamboja dengan air ini ditujukan sebagai media pemancin|g turunnya hujan.

6) Boneka Cingcowong yang terbuat dari tempurung kelapa yang dilukis menjadi Putri cantik dengan badan terbuat dari rangkaian bambu yang diberi baju dan sempur (selendang) serta diberi kalung yang terbuat dari bunga kamboja.

Untuk membuat boneka Cingcowong diperlukan peralatan sebagai berikut :

1) Bubu (dalam bahasa sunda disebut buwu) yaitu alat untuk menangkap ikan atau perangkap ikan yang terbuat dari anyaman bambu yang digunakan sebagai badan boneka Cingcowong.

2) Gayung (dalam bahasa Sunda di sebut siwur) yang terbuat dari tempurung kelapa sebagai kepalanya dan didandani sehingga menyerupai wajah wanita cantik, dalam ungkapan lain sebagai jelmaan wajah bidadari. 


\section{Gambar 1. Boneka Cingcowong}

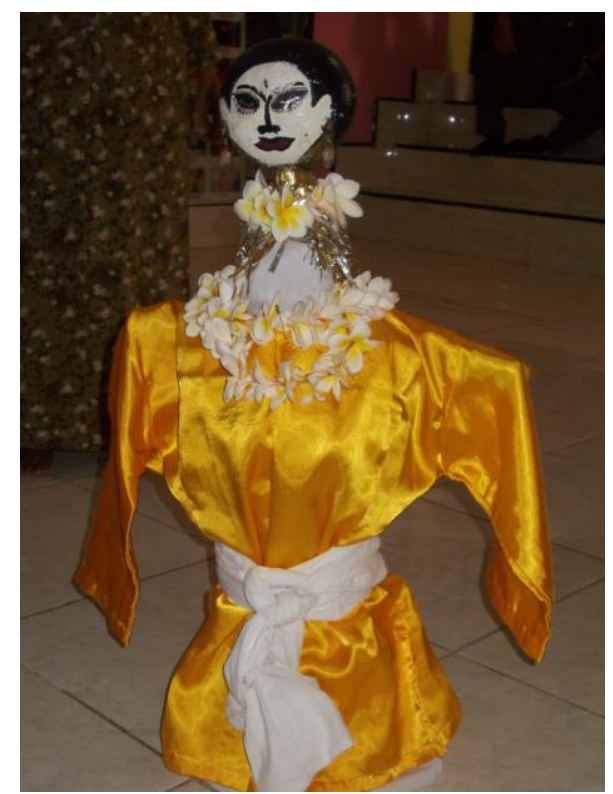

Sumber: Penelitian BPNB Bandung 2012

Selain alat utama prosesi upacara Cingcowong, terdapat pula alat-alat pengiring yang biasa dipergunakan pada pagelaran Cingcowong, di antaranya :

1) Jambangan yang terbuat dari kuningan (disebut dengan bokor/ceneng), ceneng ini difungsikan sebagai ketukan.

2) Tempayan (buyung) yang terbuat dari tanah liat untuk pengatur irama yang dipukul dengan kipas, yang terbuat dari anyaman bambu.

3) Ruas bambu sepanjang kurang lebih $20 \mathrm{~cm}$ dipergunakan untuk memukul ceneng kuningan dalam mengiringi irama buyung.

4) Hihid atau kipas dari anyaman bambu dipergunakan untuk memberikan efek suara pada buyung.

Proses persiapan upacara Cingcowong dilaksanakan beberapa saat sebelum pementasan acara Cingcowong. Selain boneka Cingcowong pada tahap awal persiapan ini disediakan pula sesajian atau sajen. Sajian dan mantra-mantra khusus yang dilafalkan oleh punduh di comberan menjadi semacam undangan bagi makhluk halus untuk datang. Berikut sesajian yang biasanya disediakan oleh punduh sebelum melaksanakan ritual Cingcowong: 
1) Parukuyan atau perdupaan atau anglo merupakan tempat pembakaran kemenyan atau arang dan bara api yang terbuat dari tanah liat.

2) Kemenyan merupakan dupa yang apabila dibakar mampu menghasilkan asap dengan aroma yang berbau menyengat. Asap yang dihasilkan kemenyan mengandung makna terhubungnya dunia manusia dengan dunia halus. Wangi asap dianggap sebagai penyampai pesan kepada makhluk halus supaya mereka dapat menghadiri acara yang akan diselenggarakan oleh manusia.

3) Cerutu dan rokok. Cerutu merupakan rokok yang terbuat dari gulungan daun tembakau kering yang melambangkan kejantanan seorang laki-laki. Roh-roh halus juga biasanya menyukai aroma yang khas dari cerutu ini.

4) Telur asin adalah simbol yang menggambarkan awal mula kehidupan di muka bumi. Telur memiliki makna mengenai cita-cita kehidupan yang akan melahirkan kebaikan.

5) Tek-tek adalah istilah masyarakat setempat untuk menyebutkan seperangkat alat yang dipergunakan untuk menyirih. Tek-tek terdiri atas sirih, gambir, kapur, dan buah pinang (jambe).

6) Congcot adalah nasi putih yang diletakkan di atas daun pisang yang telah dipincuk (dibungkus menyerupai wadah).

7) Kue atau buah-buahan manis. Kue-kue basah seperti apem, getuk, nagasari dan sebagainya serta buah-buahan seperti pisang raja, atau pisang kepok dipergunakan sebagai bahan pelengkap sesaji.

8) Gula batu merupakan jenis gula kristal berwarna putih kekuningan dengan bentuk seperti batu dengan ukuran yang sedang sebesar ibu jari atau lebih besar.

Musim kemarau merupakan waktu yang paling ideal untuk menyelenggarakan upacara Cingcowong. Pelaksanaan ritual Cingcowong biasanya dilakukan pada sore hari hingga malam hari. Namun saat ini waktu pelaksanaannya bisa lebih fleksibel. Apabila hanya untuk sekadar pagelaran bisa saja dilakukan siang hari. Adapun tempat pelaksanaannya digelar di halaman atau lapangan terbuka yang cukup luas serta mampu menampung banyak penonton. Namun saat ini bisa juga dipertontonkan di dalam ruangan yang cukup luas.

Pertunjukan upacara Cingcowong tidak dapat dilepaskan dari tahap persiapan ritualnya. Berikut ini dipaparkan tahapan persiapan yang harus dilakukan oleh seorang Punduh sebelum dilaksanakannya upacara Cingcowong.

1) Boneka didandani dengan cara mendandani dan memoles kembali boneka dan mengenakan rarangken atau asesoris berupa kalung yang terbuat dari untaian bunga 
kamboja serta mengenakan baju model kebaya warna kuning dan melilitkan sabuk dari kain katun warna putih, juga mengenakan anting-anting di bagian telinganya.

2) Mempersiapkan aneka sesajen yang terdiri atas: telur asin, tumpeng kecil atau biasa disebut congcot, cerutu, gula batu, aneka panganan kue, kembang rampe (bunga rampai) tujuh warna, dan lain-lain seperti yang sudah dikemukakan di atas.

3) Membawa boneka Cingcowong dan aneka sesajen ke parit (comberan) terdekat dan menyimpannya di tepi comberan tersebut selama satu malam. Dengan mengucapkan sejumlah mantra untuk memanggil belis (jurig) jarian dan belis (jurig) comberan, di dalam comberan tersebut punduh kemudian meminta para makhluk halus tersebut untuk masuk ke dalam boneka Cingcowong.

4) Menyediakan peralatan yang akan digunakan pada waktu upacara, seperti: taraje (tangga yang terbuat dari bambu), tikar, ember berisi air bunga rampai tujuh macam, kaca atau cermin kecil, sisir dan kemenyan beserta anglo untuk membakar kemenyan tesebut. Seluruh peralatan ini kemudian dikumpulkan di tempat yang aman di dalam rumah.

5) Nawita melakukan puasa selama tiga hari atau minimal satu hari sebelum upacara dilaksanakan.

\section{b. Tahap Pelaksanaan Upacara Cingcowong}

Para penabuh alat memainkan alatnya yaitu ibu Warsinah memukul-mukul buyungnya dengan menggunakan hihid atau kipas yang terbuat dari anyaman bambu, dan ibu Kaseh memukul-mukul bokor dengan menggunakan dua buah ruas kayu sepanjang masing-masing $20 \mathrm{~cm}$, mengiringi Sinden yang bernyanyi. Adapun lagu Cingcowong sebagai berikut.

Cingcowong-cingcowong

Bil guna bil lembayu

Shalala lala lenggut

Lenggute anggedani

Aya panganten anyar

Aya panganten anyar

Lili lili pring

Denok simpring ngaliro

Mas borojol gedog

Mas borojol gedog

Lilir guling gulinge sukma katon

Gelang-gelang layone

Layoni putra maukung 
Maukung mangundang dewa

Anging Dewa anging sukma

Bidadari lagi teka

Bidadari lagi teka

Jak rujak ranti

Kami junjang kami loko

Pajulo-julo

Teти bumiring mandiloko

Sementara itu di tengah ruangan, Nawita yang memangku boneka memasuki arena dan berjalan diantara anak tangga diikuti oleh para pengiringnya, Itit dan Nining Waskini secara beriringan dari pangkal anak tangga hingga ke ujungnya bolak balik selama tiga kali. Kemudian Nawita duduk di tengah-tengah tangga sambil tetap memangku boneka. Wajah boneka Cingcowong diperlihatkan ke arah cermin kecil yang dipegangi oleh Nining Waskini yang duduk menghadapi boneka sambil memegangi sabuk yang dikenakan boneka. Setelah selesai memperlihatkan muka boneka melalui kaca, selanjutnya Nawita memegang sisir yang digerakkan di atas kepala boneka seolaholah sedang menyisiri rambut.

Di sampingnya duduk Itit sambil ikut memegangi sabuk yang dikenakan boneka karena boneka sudah mulai bergerak mengikuti alunan lagu. Semakin lama boneka semakin bergerak ke arah kanan, kiri dan ke depan seperti tidak terkendali, tetapi tetap dipegang oleh ketiga orang tersebut. Boneka Cingcowong ini mulai bergerak setelah kalimat terakhir dari lagu di atas diucapkan.

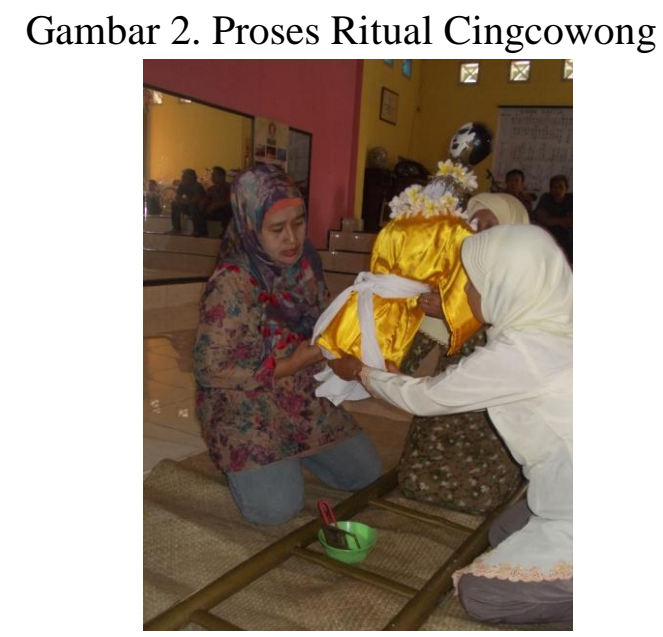

Sumber: Penelitian BPNB Bandung 2012 
Boneka Cingcowong selain bergerak bisa juga mengejar penonton yang tidak percaya bahwa boneka tersebut telah dirasuki roh gaib, bahkan bisa juga mengejar-ngejar karena suka kepada seseorang dan orang-orang yang mengolok-oloknya dengan kata-kata : “Cingcowong cingcowong, hulu canting awak bubu” (Cingcowong cingcowong kepala canting badan bubu). Kemudian air dan bunga kamboja yang telah dipersiapkan dalam wadah diciprat-cipratkan ke arah penonton dan jalan yang dilewati Cicngcowong berkeliling sambil mengucapkan kata-kata "Hujan...Hujan...Hujan..."

\section{c. Cingcowong sebagai Tarian}

Keberadaan tarian Cingcowong tidak dapat dilepaskan dari ritual Cingcowong sebagai inspirasinya. Bermula ketika pada tahun 2004 Dinas Pariwisata dan kebudayaan Kabupaten Kuningan memerlukan sebuah ikon kesenian untuk diusung pada perlombaan Gelar Budaya di tingkat Provinsi Jawa Barat, adalah Uha Juahaeni yang mempelopori gagasan dibuatnya tarian Cingcowong yang dianggapnya menarik dan mampu dijadikan ciri khas sebagai ikon kesenian Kabupaten Kuningan. Penciptaan karya seni Cingcowong ini tentunya dilakukan atas dasar persetujuan dari punduh Nawita sekalu punduh Cingcowong. Namun sayangnya pementasan tari Cingcowong yang hanya dilakukan satu kali saja itu terhenti begitu saja, tidak ada tindak lanjut dari pemerintah daerah setempat untuk benar-benar menggiatkannya sebagai sebuah karya seni yang bersifat kolektif.

Pada tahun 2006 Dede Nono Rukmana melalui Sanggar Seni DNR yang dimilikinya beserta rekan sejawatnya dari STSI Bandung tergugah untuk kembali mengangkat seni tari Cingcowong sebagai sebuah karya seni baru dari daerah Kuningan, dengan tetap berpedoman pada tradisi ritual Cingcowong yang telah ada sebelumnya. Dengan alasan untuk menjaga kelestarian ritual Cingcowong yang mulai banyak dinafikan oleh masyarakat, maka terciptalah tari Cingcowong versi baru yang benar-benar mengadopsi prosesi ritual Cingcowong yang sebenarnya.

\section{Cingcowong dari Sakral ke Profan}


Menurut hasil kajian sejarah belum dapat dipastikan sejak kapan ritual Cingcowong muncul, namun apabila menilik keberadaan punduh Cingcowong saat ini yang merupakan generasi ke-4, hal tersebut kemudian dapat diperkirakan bahwa Cingcowong pertama kali muncul sekitar awal abad ke-20. Pada periode ini menurut catatan sejarah, agama Islam telah masuk ke Pulau Jawa, khususnya Jawa Barat ${ }^{3}$. Namun demikian sebelum agama Islam masuk ke Tatar Jawa, pengaruh akulturasi agama dan budaya Hindu-Budha terhadap budaya Jawa sudah mengakar kuat, sehingga tidak mudah menghilangkannya begitu saja ${ }^{4}$.

Sejak awal budaya Jawa yang dihasilkan pada masa Hindu-Budha bersifat terbuka untuk menerima apa pun dengan pemahaman bahwa semua agama itu baik, maka sangatlah wajar jika kebudayaan Jawa berisifat sinkretis ${ }^{5}$. Termasuk juga ketika agama Islam hadir sebagai pembaharu, budaya dan kepercayaan Hindu-Budha masih tetap dipertahankan meskipun dalam bentuk dan pemahaman yang berbeda ${ }^{6}$. Kepercayaan masyarakat terhadap sesuatu hal yang gaib dan sakti seperti misalnya roh dewa-dewi dan nenek moyang masih dipercayai sebagai sebuah kekuatan yang maha dahsyat yang ada di sekitar manusia. Oleh karena itu ritual-ritual yang berkaitan dengan penghormatan terhadap makhluk-makhluk gaib juga masih kerap dilaksanakan, padahal sebetulnya hal tersebut bertentangan dengan konsep dasar ajaran agama Islam yang telah mereka anut.

Ritual keagamaan merupakan suatu sarana untuk mengaktualisasikan rasa dan emosi sebagai ungkapan rasa syukur dan permintaan perlindungan kepada Tuhan dan kekuatan yang berada di luar pemikiran manusia. Ritual dapat bersifat profan dan dapat pula bersifat sakral bergantung dari esensi dan maksud yang dikandung dalam pelaksanaan upacara tersebut.

Konsep sakral dan profan yang diketengahkan Durkheim pada ritual keagamaan, memberikan pengertian bahwa pada ritual Cingcowong di Kabupaten Kuningan juga konsep sakral dan profan itu ada. Konsep sakral yang lebih menekankan pada adanya

\footnotetext{
${ }^{3}$ Penyebaran agama Islam ke tatar Parahyangan (Jawa Barat) pada abad XIV Masehi disebabkan oleh adanya arus perdagangan di kota-kota pelabuhan Jawa Barat. Cirebon merupakan daerah yang paling awal penduduknya bergama Islam.

${ }^{4}$ Islamisasi di Indonesia berlangsung dengan tanpa melupakan sejarah lamanya. Artinya, unsurunsur Jawa-Hndu tidak dihilangkan begitu saja, tapi sering terjadi tradisi Jawa-Hindu dipergunakan sebagai alat media dakwah untuk menyebarkan agama Islam.

${ }^{5}$ Sinkretisme adalah pencampuradukan beberapa ritual keagamaan yang berbeda. Dalam Kamus Besar bahasa Indonesia disebutkan : "Paham (aliran) baru yg merupakan perpaduan dari beberapa paham (aliran) yang berbeda untuk mencari keserasian, keseimbangan."

${ }^{6}$ Dari banyak unsur tradisi Hindu-Jawa yang tetap bertahan beberapa di antaranya adalah teori kesaktian, tapa dan tradisi wayang (Woodward, 2012:236)
} 
konsep kesucian dari suatu benda atau hal yang berkaitan dengan ritual, serta konsep profan yang menunjukkan pada suatu benda atau hal yang bersifat biasa.

Lalu seperti apakah yang dimaksudkan dengan the secred (yang keramat) pada ritual Cingcowong sebenarnya? Seperti diungkapkan di atas bahwa the secred dan ritualritual yang ada di masyarakat memiliki cakupan yang lebih jauh daripada agama. The secred merupakan sebuah ikatan primodial masyarakat yang memiliki sifat mempersatukan. Bila dilihat dalam ritual Cingcowong hal yang menjadi faktor pemersatu masyarakat dalam mempercayai Cingcowong sebagai ritual untuk menurunkan hujan berada pada tataran kognisi masyarakat, yaitu kepercayaan bersama. Kepercayaan bersama terhadap adanya sebuah kekuatan gaib yang dapat membantu mereka memberikan hujan inilah yang kemudian menjadi secred center masyarakat di Desa Luragung Landeuh. Sebuah secred center apabila dibentuk sebagai fokus identitas kolektif masyarakat dapat dituangkan dalam bentuk kebendaan yang bersifat nyata. Boneka Cingcowong kemudian dipilih sebagai sebuah simbol ${ }^{7}$ oleh punduh untuk mediasi kekuatan alam gaib dengan ekspektasi di dunia nyata, sehingga terciptalah apa yang dikehendaki oleh masyarakat itu yaitu turunnya hujan.

Dalam kaitannya dengan ritual Cingcowong, kekuatan gaib dari bidadari dan makhluk halus penghuni comberan yang merasuki tubuh boneka Cingcowong menunjukkan keyakinan manusia terhadap hal-hal yang bersifat gaib dalam wujud kekuatan yang luar biasa yang menjadi sebab terjadinya hal-hal luar biasa. Kekuatankekuatan di atas menurut Marett (Keontjaraningrat, 1987:60-62) disebut sebagai kekuatan supranatural atau kekuatan gaib. Kekuatan yang oleh Marett juga dimiliki oleh manusia. Kekuatan-kekuatan tersebut juga terdapat pada boneka Cingcowong, yang menimbulkan rasa keramat atau sakral yang diakibatkan adanya rasa percaya kepada hal-hal gaib.

Untuk menjaga keberadaan ritual Cingcowong agar senantiasa lestari, diperlukan adanya sebuah upaya untuk membangun memori kolektif yang kuat pada masyarakat pendukungnya. Nilai-nilai tradisional yang terkandung dalam ritual Cingcowong kemudian dijadikan sebagai pengikat identitas masyarakat di Desa Luragung Landeuh. Keberadaan punduh Cingcowong berperan penting dalam melestarikan nilai-nilai kultural ini dalam ingatan kolektif masyarakat di Desa Luragung Landeuh. Oleh sebab itulah, melalui punduh the secred kemudian dimodifikasi dalam bentuk ritual Cingcowong

${ }^{7}$ Di daerah lain beberapa ritual untuk menurunkan hujan dilakukan dengan kucing sebagai simbolnya. Seperti Ngarak Kucing di Kabupaten Tangerang dan Manten Kucing di daerah Banyuwangi. 
sehingga tercipta sebuah kesan keramat atas peristiwa atau fenomena tersebut. Kesan yang semakin menguat inilah yang tidak mudah untuk dilupakan begitu saja hingga kemudian menjadi memori kolektif masyarakat setempat. Terciptanya memori kolektif tidak terjadi begitu saja, hal ini ada karena didasari oleh adanya pengalaman bersama (sharing of experience) antara warga masyarakat. Dalam konteks ritual Cingcowong, pengalaman bersama ini diperoleh dari adanya sugesti bersama terhadap fenomena hujan yang kerap kali muncul manakala ritual Cingcowong dilakukan.

Ritual Cingcowong yang ada di Desa Luragung Landeuh merupakan sebuah bentuk kesadaran kolektif terhadap pensakralan suatu fenomena atau benda. Sebagaimana diutarakan Koentjaraningrat bahwa kesadaran kolektif ini berawal dari adanya kesadaran individu terhadap fenomena kemarau panjang yang terjadi di Desa Luragung Landeuh, dalam hal ini punduh. Melalui gagasan individu punduh yang diperolehnya dari proses tirakat inilah kemudian terbentuk gagasan kolektif ritual Cingcowong seperti yang kita kenal saat ini.

Pelaksanaan upacara yang bersifat profan lebih banyak dimaksudkan untuk memperingati suatu peristiwa tertentu seperti upacara-upacara yang berkenaan dengan daur hidup manusia yaitu kehamilan, kelahiran, pernikahan dan kematian. Adapun upacara yang bersifat sakral lebih tertuju pada upacara keagamaan atau upacara yang berkaitan dengan kepercayaan terhadap Tuhan maupun terhadap kekuatan-kekuatan lain yang dianggap mempunyai kekuatan dahsyat atau besar (Rosyadi, 2008:68-69).

Dari berbagai perlengkapan yang dipergunakan untuk melakukan ritual Cingcowong, terdapat beberapa peralatan yang dianggap sakral dan profan. Peralatan yang dianggap sakral di antaranya yaitu sesajian, boneka, buyung dan bokor, sedangkan yang lainnya seperti tikar, cermin, sisir, tangga dan bunga kamboja dianggap profan karena berfungsi hanya sebagai pelengkap. Selain peralatan, tempat dan waktu ritual juga turut berubah. Tempat ritual yang biasanya harus dilakukan di lapangan terbuka dan luas, saat ini dapat dilakukan di dalam ruangan tertutup. Begitupun dengan waktu pertunjukan, biasanya hanya dapat digelar apabila sore hari menjelang malam Jum'at pada saat musim kemarau, namun saat ini dapat digelar kapan saja sesuai dengan permintaan pemesan. Jelaslah kini bahwa ritual Cingcowong yang ada saat ini telah mengalami perubahan makna dan fungsi dari sakral ke profan.

\section{Cingcowong dan Perubahan Fungsi}


Sebagaimana yang diketahui bahwa ritual Cingcowong pada awalnya dimaksudkan sebagai media penghubung antara alam manusia dan alam gaib guna mememohon turunnya hujan. Namun seiring perkembangan waktu dan terutama sekali pengetahuan masyarakat terhadap konsep nilai budaya dan agama yang ada saat ini, menjadikan ritual Cingcowong kemudian hanya dianggap sebelah mata oleh pihak-pihak tertentu, bahkan oleh sebagian masyarakat dikategorikan sebagai kegiatan syirik $^{8}$ karena bertentangan dengan ajaran agama Islam yang dianut oleh mayoritas penduduk setempat.

Kondisi ritual Cingcowong yang ada saat ini semakin terpuruk karena banyak yang menentang kegiatannya, namun oleh sebagian lainnya ritual Cingcowong justru dianggap sebagai suatu hal yang penting dan harus tetap dilestarikan keberadaannya, sekalipun dalam bentuk yang berbeda supaya dapat lebih diterima oleh masyarakat. Timbullah pemikiran untuk membuat sebuah karya seni tari dengan ritual Cingcowong sebagai ide utamanya. Seni tari yang bersifat profan diciptakan supaya masyarakat dapat menikmati warisan budaya ritual Cingcowong yang semakin terpinggirkan tanpa harus diikuti oleh perasaan bersalah karena merasakan sugesti yang timbul dari ritual Cingcowong. Seni tari yang bersifat profan diharapkan mampu menjawab kegamangan masyarakat terhadap adanya praktik-praktik syirik yang muncul dari ritual Cingcowong. Kondisi demikian jelas memberikan efek yang cukup signifikan terhadap keberadaan ritual Cingcowong di Desa Luragung Landeuh. Masyarakat mulai menyadari bahwa sebenarnya fenomena alam yang terjadi pada saat ritual Cingcowong selesai digelar, hanya kebetulan saja dan bukan semata-mata fenomena gaib yang timbul akibat adanya campur tangan makhluk gaib penunggu comberan, oleh karena itu ritual Cingcowong tersebut tidaklah harus dipercayai apalagi disakralkan.

Fenomena empirik mistik inilah yang dicoba untuk ditengahi oleh para seniman di Kabupaten Kuningan dengan mengetengahkan konsep Cingcowong sebagai sebuah seni tari. Adanya perubahan paradigma dengan menggantikan secred center terhadap kekuatan supernatural menjadi non-supernatural, membawa Cingcowong pada sebuah perubahan fungsi. Fungsi-fungsi sakral yang dianggap agung, tinggi dan dihormati yang dulu sekiranya dipercaya ada telah tergantikan dengan fungsi-fungsi profan yang bersifat biasa pada hal-hal yang sama.

\footnotetext{
${ }^{8}$ Syirik dalam ajaran Islam merupakan segala sesuatu yang mengalihkan perhatian dari persoalan kesatuan dengan Allah. Mempercayai adanya kekuatan gaib dari makhluk lain selain kekuatan Allah adalah salah satu perbuatan syirik
} 
Secara umum hal tersebut tidaklah menjadi permasalahan penting bagi punduh sebagai pelaku utama ritual Cingcowong, karena walau bagaimanapun mereka menyadari penerimaan masyarakat terhadap konsep sakral yang terdapat pada ritual Cingcowong sudah mulai luntur seiring dengan perkembangan kemajuan zaman. Apalagi bila ditelaah lebih lanjut, khususnya pada generasi muda yang ada di Desa Lurangung Landeuh sendiri, hampir sebagian besar dari mereka tidak mengenal apa dan bagaimana yang dimaksud dengan ritual Cingcowong yang memang sudah jarang ditampilkan secara umum di tempat mereka.

Untuk menyiasati kevakuman tradisi Cingcowong serta adanya keinginan dari para pelaku dan sebagian masyarakat untuk kembali mengenalkan tradisi Cingcowong kepada masyarakat khususnya generasi muda, maka ritual Cingcowong kembali dipentaskan pada acara-acara yang bersifat umum seperti perayaan ataupun keriaan hingga pagelaran seni budaya. Kondisi ini sedikit banyak berpengaruh terhadap kehidupan perekonomian para pelaku ritual Cingcowong, sebab dari pementasan itu mereka dapat meraup keuntungan walaupun tidak seberapa. Tidak adanya pantangan atau tabu yang diakui punduh dalam mementaskan ritual Cingcowong saat ini, semakin mempertegas adanya perubahan fungsi ritual Cingcowong ke arah yang lebih profan.

\section{PENUTUP}

Penjelasan di atas sekiranya dapat menuntun kita pada sebuah kesimpulan akhir mengenai fenomena yang terjadi pada ritual Cingcowong di Desa Luragung Landeuh, Kecamatan Luragung, Kabupaten Kuningan. Penulis menyimpulkan bahwa ada 2 faktor penting yang mempengaruhi terjadinya perubahan ritual Cingcowong yang asalnya bersifat sakral kepada hal-hal yang bersifat profan. Kedua faktor itu adalah faktor ekternal dan faktor internal.

Timbulnya pandangan masyarakat yang menganggap bahwa ritual Cingcowong sebagai bentuk praktik yang bertentangan dengan syariat agama Islam, kemudian menggiring Cingcowong pada sebuah transformasi bentuk hingga melahirkan sebuah bentuk baru seni tari Cingcowong. Sekalipun faktor ekternal yang ada belum begitu kuat mempengaruhi eksistensi ritual Cingcowong, namun secara perlahan namun pasti keberadaan ritual Cingcowong mulai terpinggirkan. Inilah rupanya yang menjadi penyebab terjadinya perubahan ritual Cingcowong secara eksternal. 
Kondisi tersebut secara tidak langsung ternyata memberikan dampak yang cukup signifikan terhadap eksistensi ritual Cingcowong, utamanya bagi para pelakunya yang dimotori oleh punduh Cingcowong. Meskipun bukan merupakan matapencaharian utama, namun harus diakui bahwa pementasan ritual Cingcowong telah memberi pemasukan yang cukup bagi penghidupan mereka sehari-hari. Oleh karena saat ini mulai jarang ditampilkan atau dipanggil untuk tampil oleh masyarakat yang berkepentingan khususnya petani- untuk memanggil hujan, maka saat ini mereka menjadi lebih terbuka terhadap semua kesempatan yang datang kepada mereka. Dahulu Cingcowong mungkin hanya digelar pada saat musim kemarau saja dengan satu tujuan yaitu mendatangkan hujan, namun saat ini Cingcowong dapat dipentaskan kapan dan dimana saja dengan tujuan yang lebih umum dan terkesan lebih komersil ${ }^{9}$. Betapa tidak, ternyata saat ada harga yang ditetapkan oleh punduh untuk pementasan Cingcowong, padahal dahulu tidak demikian. Kemampuan punduh sebagai seorang yang ahli dalam mendatangkan hujan serta kerap dinilai memiliki kharisma mistis cukup diakui dan di hormati ditengah masyarakat, namun saat ini kharismanya mulai berkurang seiring dengan melunturnya nila-nilai sakral ritual tersebut. Materi sebagai dasar pemenuhan kebutuhan hidup ternyata mampu mengubah hal-hal yang dahulunya bersifat sakral menjadi suatu hal yang profan, hal inilah yang sekiranya menjadi salah satu faktor perubahan yang muncul secara internal dalam ritual Cingcowong.

Untuk melengkapi hasil penelitian ini, sekiranya dibutuhkan beberapa rekomendasi yang mungkin dapat berguna bagi pelestarian karya budaya ritual Cingcowong ini di masa yang akan datang. Tidaklah berlebihan bila penulis mengharapkan bahwasanya hasil penelitian ini dapat dijadikan sebagai sebuah acuan untuk penelitian lebih lanjut, utamanya berkenaan dengan hal-hal lain yang sekiranya belum terkaji dalam penelitian ini.

Dalam tataran praktis, kajian ini diharapkan mampu memberikan sumbangsih, khusunya dalam hal:

1. Pelestarian eksistensi ritual Cingcowong seharusnyalah tetap dipertahankan keberadaannya, dengan salah satunya memberikan apresiasi yang layak kepada para tokohnya.

\footnotetext{
9 Seringkali saat ini masyarakat yang mengundang punduh untuk mementaskan ritual Cincgcowong bukan dari kalangan petani atau masyarakat setempat, tetapi juga dari kalangan pemerintahan atau lembaga lain demi kepentingan yang lebih luas seperti; gelar budaya, dan penelitian ilmiah. Sehingga secara tidak langsung mereka mendapatkan keuntungan finansial daripadanya.
} 
2. Diperlukan adanya sinergi yang baik antara masyarakat, tokoh seni dan pemerintah daerah setempat untuk mempertahankan ritual Cingcowong, sehingga penilaian yang terjadi bukan sekadar pada tataran dogmatis tetapi lebih luas mencakup nilai-nilai tradisional yang terkandung di dalamnya yang sekiranya layak dijaga demi mempertahankan memori kolektif masyarakat.

\section{DAFTAR SUMBER}

Adimihardja. Kusnaka. 1993.

Kebudayaan dan Lingkungan. Bandung: Ilham Jaya.

Amsar, Teguh. Et.al, 1975.

Sejarah Jawa Barat; Dari Masa Pra Sejarah Hingga Masa Penyebaran Agama Islam. Bandung: Proyek Peningkatan Kebudayaan Nasional Provinsi Jawa Barat.

Durkheim, Emile. 1995

The Elementery Form of Religious Life. New York: Karen E Fields (Introduction). The Free Press.

Iskandar, Johan.1992.

Perladangan di Indonesia; Studi Kasus dari Daerah Baduy, Banten Selatan, Jawa Barat. Jakarta: Djambatan.

Koentjaraningrat. 1987.

Sejarah Teori Antropologi I. Jakarta: UI Press.

Kusnadi, Edi. 2001

Seni Cingcowong di Desa Luragung Landeuh, Kecamatan Luragung, Kabupaten Kuningan: Suatu Tinjauan Awal. Bandung: STSI .

Narbuko, Cholid dan Achmadi, H. Abu. 2012.

Metodologi Penelitian. Jakarta: Bumi Aksara.

Pals, Daniel L. 2011.

Seven Theories of Religion: Tujuh Teori Agama Paling Komprehensif. Jogjakarta: IRCiSoD.

Rosyadi. et.al. 2005.

Upacara Ngaruat Bumi pada Komunitas Adat di Kampung Nagara Banceuy di Desa Sanca, Kecamatan Jalan Cagak, Kabupaten Subang. Bandung: Balai Pelestarian Sejarah dan Nilai Tradisional Bandung.

Sutrisno, Mudji \& Putranto, Hendar (Ed). 2005.

Teori-Teori Kebudayaan. Jakarta: Kanisius.

Woodward, Mark R. 2012.

Islam Jawa; Kesalehan Normatif Versus Kebatinan. Yogyakarta: LkiS. 